\title{
Women Farmers and Agricultural Innovation: Marital Status and Normative Expectations in Rural Ethiopia
}

\author{
Lone Badstue ${ }^{1, *(1)}$, Patti Petesch $\left.{ }^{2} \mathbb{(}\right)$, Cathy Rozel Farnworth ${ }^{3}$, Lara Roeven ${ }^{4}$ \\ and Mahlet Hailemariam ${ }^{5}$ \\ 1 Gender \& Social Inclusion, International Maize and Wheat Improvement Center, CIMMYT Int., \\ Texcoco 56237, Mexico \\ 2 Knowledge, Technology and Innovation Group, Wageningen University and Research, \\ 6700 Wageningen, The Netherlands; patti@pattipetesch.com \\ 3 Independent Researcher, 48145 Münster, Germany; Cathyfarnworth@hotmail.com \\ 4 International Maize and Wheat Improvement Center, CIMMYT Int., Texcoco 56237, Mexico; \\ 1.roeven@cgiar.org \\ 5 Independent Researcher, 1176 Addis Ababa, Ethiopia; mahailemariam@gmail.com \\ * Correspondence: lone.badstue@gmail.com or 1.badstue@cgiar.org
}

Received: 28 September 2020; Accepted: 1 November 2020; Published: 25 November 2020

\begin{abstract}
Sustainable agricultural development depends on female and male smallholders being effective farmers. This includes the ability to access or control resources and make the best decisions possible agro-ecologically, economically, and socially. Traditionally, gendered studies on innovation practice focus on female- versus male-headed households. In this paper, we focus on married women in acknowledged male-headed households and women heading their own households to examine how marital status influences women's capacity to innovate in their rural livelihoods. Using data from eight community case studies in Ethiopia, we used variable-oriented and contextualized case-oriented analysis to understand factors which promote or constrain women's innovative capacities. We use Kabeer's Resources-Agency-Achievements framework to structure our findings. Single women are more likely to own land and experience control over their production decisions and expenditures than married women, but engage in considerable struggle to obtain resources that should be theirs according to the law. Even when land is secured, customary norms often hamper women's effective use of land and their ability to innovate. Still, some single women do succeed. Married women can innovate successfully provided they are in a collaborative relationship with their husbands. Finally, we find that gender-based violence limits women's achievements. The article concludes with recommendations.
\end{abstract}

Keywords: sustainable development; women; marital status; gender norms; capacity to innovate; wheat; maize; Ethiopia

\section{Introduction}

The 2020 Global Gender Gap Report ranked Ethiopia 82nd out of 153 countries, up from 100th in 2006 [1]. This overall progress is explained by, among others, considerable comparative advances in political empowerment (61st in 2006: 16th in 2020) and in health and survival (respectively, 87th in 2006 and 63rd in 2020). At the same time, the overall ranking masks a significant loss in women's ability to participate in economic opportunity (from 74th in 2006 to 125th in 2020) and notable comparative weakening in educational attainment (from 108th in 2006 to 140th in 2020 [1]. National efforts to strengthen gender equality include the Gender Equality Strategy for Ethiopia's Agriculture Sector [2]. Its strategic objectives include strengthening the gender responsiveness of agricultural extension. 
To achieve this, it has sex-disaggregated targets for extension of coverage to households with male and female heads, married women in male-headed households, pastoralists, and agro-pastoralists. Other strategic objectives include increasing women's participation in decision-making at all levels and improving policies, structures, and systems in the agricultural sector. Attaining these objectives requires addressing the complexity of gender relations in agriculture, the persistence of strong cultural norms (which are highly regionally differentiated), and limited technical gender research and implementation capacity at all levels [2-4].

Gender inequalities, such as those experienced across Ethiopia, have internationally recognized consequences for agricultural sustainability and poverty alleviation [5-8]. Sustainable Development Goal (SDG) 2 is Zero Hunger. To support this, Target 2.3 aims, by 2030, to "double the agricultural productivity and incomes of small-scale food producers, in particular women ... through secure and equal access to land, other productive resources and inputs, knowledge, financial services, markets and opportunities for value addition, and non-farm employment" [9]. Target 5A (under SDG 5, Gender Equality) aims to "undertake reforms to give women equal rights to economic resources, as well as access to ownership and control over land and other forms of property, financial services, inheritance, and natural resources, in accordance with national laws" [10]. Omilola and Robele [11] argue "gender equality acts as an enabler and an accelerator for all SDGs through its fundamental role in human development. It is impossible to achieve sustainable development as long as one half of humanity continues to be denied its full human rights and opportunities." However, moving towards gender equality in the smallholder sector is fraught with difficulty. Smallholders are affected by multiple challenges ranging from the climate crisis to profound underinvestment in the sector, made more complex by deep, intersecting political, economic, identity, and geographic vulnerabilities (ibid.), which, in turn, create "pockets of marginalization and exclusion" [11] (p. 10). Kabeer [12] discusses how identity-based discrimination—gender, race, caste, ethnicity—contributes towards the development of group-based horizontal inequalities that are experienced in highly personal ways. Gender-based and other inequalities make it harder to increase productivity, reduce poverty and hunger, and ensure that livelihoods are truly sustainable $[13,14]$.

In this article, we consider the processes of marginalization and exclusion-inclusion as they affect married women in male-headed households, henceforth referred to as married, vis-à-vis separated/divorced/widowed/never-married women, henceforth referred to as single women (we refer to their specific marital status if this brings interpretative value). We use the terms innovate and innovation in a broad sense to refer to new ways of doing things related to agriculture, regardless of whether these are externally introduced or developed by farmers themselves [15]. To ensure high diversity across the study sites in terms of both farming systems and sociocultural dimensions, we use data from eight maize- and/or wheat-growing communities in three different regions in Ethiopia. We particularly draw on a subset of interviews and focus group discussions with women in these communities. Our specific interest is to explore the ways in which marital status influences the capacity of smallholder women to innovate in agriculture, and more broadly in their lives. To do this, we examine how married and single women in our dataset access productive resources (particularly land, labor, and, to a lesser degree, credit), and the degree to which they express agency in their everyday lives. This approach is inspired by Kabeer's [16] framing of the ability to exercise choice as composed of three interrelated dimensions: Resources (pre-conditions), Agency (process), and Achievements (outcomes). Resources, including material, human, and social resources, underpin the ability to make meaningful choices. Agency is the ability to define one's goals and-critically-to act upon them. Achievements refers to evidence that empowerment has actually happened [16].

The article opens with an overview of the literature on differences in capacity to innovate in maizeand wheat-based agriculture between married and single women in Ethiopia, before moving on to discuss female-headedness, the degree to which women are conceptualized as farmers in Ethiopia, and the gendered access to resources. We then present the research methodology. The Results section commences with an overview of typical innovations deployed by women in the case studies, after which 
the remainder of our findings are structured according to Kabeer's Resources-Agency-Achievements perspective mentioned above [16]. We apply this thinking to explore how access to resources and factors related to agency shape women's demonstrated capacity to innovate-hence, achievements-in their agricultural livelihoods. We conclude the paper by highlighting the implications for ensuring that married and single women can innovate to move forward in their lives.

\subsection{Literature Review}

\subsubsection{Gender and the Adoption of Improved Maize and Wheat Varieties in Ethiopia}

We begin this section by considering the ability to adopt improved crop varieties as a useful proxy indicator for women farmers' decision-making power with regards to agricultural innovation. Traditionally, adoption studies have tended to focus on the gender of the household head. However, this ignores the behavior of most women, who live and farm in male-headed households (MHHs), and thus provides limited insights about broader gender dynamics $[17,18]$. However, it is well established that women and men within a household may manage different plots, crops, and livestock and be responsible for different kinds of decisions $[19,20]$. Gender-based variations in access to, control over, and deployment of resources-and the ability to benefit from one's own contributions to the household economy-may contribute towards different productive and development outcomes for various household members [20-22]. At the same time, women are not necessarily passive in the face of gender-based inequalities. Research in Zimbabwe, for instance, exposed highly complex and subtle bargaining and strategizing by women in households to access stored maize. These varied across the season, involved acceptance of apparent defeats to secure later gains, and required shrewd alliances with different household members [23]. Such observations highlight the fact that gender is, in many ways, a performance [24], and that women may travel 'hidden pathways' on their journeys towards empowerment [25].

Few comparative adoption studies that address gender have been conducted in Ethiopia. O'Brien et al. [25] examined the relative ability of women in MHHs vis-à-vis male household heads to adopt and utilize quality protein maize (QPM). They found lower adoption rates among married women than their spouses. The reasons included women's weaker access to agricultural extension, lower awareness of QPM, and less input into decisions around key aspects of adoption, production, and marketing. Kassa et al. [26] researched the adoption of improved maize varieties (IMVs) in the West Harerghe Zone. While farm size significantly affected adoption decisions of IMVs by MHHs, with younger men with large farms being more likely to adopt than men with smaller lands, it did not significantly affect the adoption of IMVs by FHHs. The key determinants were that women heads of households were less educated and had weaker access to extension services, and thus tended to lack information about IMVs. Gebre et al. [13] researched the adoption of IMVs in southern Ethiopia and found maize productivity in MHHs to be $44.3 \%$ higher than in female-headed households (FHHs). However, if FHHs were able to use their resources as effectively as MHHs, their productivity would increase by $42.3 \%$. MHHs have a higher number of family members to provide labor, larger land size, and better financial access than FHHs. Furthermore, the authors differentiate de facto FHHs and de jure FHHs. The former benefit from a higher number of adult male family members to provide labor, more livestock, and smaller land size than the latter [13].

Tiruneh et al. [27] researched wheat adoption in the Central Highlands. In 1997, about 59\% of MHHs and $42 \%$ of FHHs grew wheat. Of these, a significantly higher proportion of MHHs (30\%) grew improved wheat varieties (IWV) compared to FHHs (14\%). For MHHs, interactions with the extension services dramatically increased the odds in favor of adopting IWVs by a factor of 22.1. For FHHs who used radio to access extension messaging, adoption of IWVs improved by a factor of 5.9. In both household typologies, land size was important. Whilst the average farm size, area under wheat, and livestock units were significantly higher for MHHs than FHHs, the probability of adopting 
IWVs increased almost equally for MHHs and FHHs if farm sizes were increased for women [27]; see similar findings in relation to other crops in Ragasa et al. [28].

A study of trait preferences in wheat in Ethiopia [29] showed that the number of productive tillers was the most important overall trait for both women and men. Many women farmers also showed a preference for older, local varieties, associating these with better quality for local dishes and as roofing materials, while men preferred marketable, high-yielding, rust-resistant varieties. Importantly, very few women had cooked any of the improved varieties because they have a high market value as seed-a market that is largely controlled by men. Gendered information asymmetry thus meant it was difficult to properly assess women's trait preferences [29]. Furthermore, most respondents in married households claimed that both genders contribute to decisions around varietal choices. However, men asserted that a decision was joint unless the wife disagreed, in which case the man takes the decision [29].

\subsubsection{Female Headedness in Ethiopia}

Many factors contribute to the formation of FHHs in Ethiopia. Research conducted in South Gondar showed that FHHs form due to divorce, domestic violence, polygamy, death of spouse, and desertion, as well as because some women never marry. Families can disintegrate due to impoverishment, the impact of illness and disease like malaria and HIV/AIDS, health issues such as fistula, conflict over household resources, migration, adultery, sexual incompatibility, and barrenness of the woman. Some women do not marry because they are involved in locally despised occupations, such as tanneries. Others may be ostracized as slaves or witches [30]. Tiruneh et al. [27] remark that location-specific research into the specific processes whereby female-headed households are formed is important, as this can vary. They further observe that women may choose not to marry or choose to live separately from their husbands [27]. This comment suggests that it is important to appreciate that some women may become single through no agency of their own, but that other women make a positive choice to live apart from a man. The multiplicity of reasons why women may be single also has important bearing on the types of community support that single women may expect as well as the resources they may access.

Research from Ethiopia suggests that it is erroneous to consider women heads of households as fully autonomous. Rather, they occupy a kind of liminal zone between integration and isolation [31]. On the one hand, FHHs are recognized as a distinctive household type by policymakers. The current Growth and Transformation Plan (GTP) II and the Gender-Equality Strategy for Ethiopia's Agricultural Sector (GESEA) (2017) distinguish between MHHs and FHHs, and the strategy attempts to reach women in MHHs as well [4,32]. On the other hand, cultural norms mean that single women can face constraints on their agency; for example, many frequently consult male relatives before deciding whether to innovate with new technologies and practices [33].

\subsubsection{Perceptions of Women as Farmers in Ethiopia}

Ethiopian women perform a wide range of critical activities in farming $[4,29,34]$. However, they are almost never considered to be farmers. In Ethiopia, a farmer is constructed as someone who can independently plow, sow and harvest, all of which are core farming activities. Plowing is argued to be a 'man's activity' that is too difficult for women [29]. Gella and Tadele [34] contest the narrative about the physical difficulty of plowing and find more potent explanations in cultural narratives. Aboma [34] found that among the Maqi Oromo, plowing and sowing are exclusively male activities because both women and the land are considered to bear the man's fruit. A woman plowing the land is akin to 'a woman tilling a woman' [34] (p. 71). Masefield [34] found that some communities believe that should women be accepted as farmers with the same level of assets as men, they would engage in repeated marriage and society would fall apart. In other words, the very concept of a woman farmer can be transgressive of the social order. Gella and Tadele [34] suggest that the consequences of excluding girls and women from these central activities mean that it is considerably harder for them to 
farm independently without reliance on men. The authors also rue other consequences; for example, rural advisory services tend to marginalize women, and even programs such as land certification, which provide for joint titling, fail in their view to maximize their impact because policymakers and implementing agencies themselves do not fundamentally challenge the concept of farmers as men. This leads to a process, they argue, whereby women are constantly re-marginalized from farming and farming narratives and remain dependent on men for core agricultural tasks and other resources.

Nelson [29] points out, however, that women are involved in plowing to the extent that they follow the plow and break up large clods using a hand tool. They are also involved in fungicide and herbicide application, commonly seen as men's work, through carrying huge quantities of water (100-1000 L per hectare depending on the product), sometimes across several kilometers. Gella and Tadele [34] also found, in their fieldwork, that some-though few-women plow.

Taken together, these findings suggest that women play a critical role in farming processes, yet their contribution, and even their physical presence in the field, appears to be made invisible through a potent narrative that constructs farmers as male.

\subsubsection{Gendered Access to Resources: Land, Labor, and Finance in Rural Ethiopia}

Traditionally in Ethiopia, gender norms related to property ownership, inheritance, and the division of assets after divorce favor men [35]. However, ethnic and regional diversity suggest that women in the north enjoy a higher overall status and potentially stronger bargaining power than women in the south [14,36]. The Family Code (2000), initially implemented in Tigray, Amhara, and Oromia, with a revised Code implemented nationally in 2011, provides women and men with equal rights and access to assets during marriage. Upon divorce, assets are to be distributed between husband and wife [36]. Ethiopia's fourth constitution (1995) provides for equal rights for women and affirmative action to redress discrimination in employment and pay [2], and the Second Growth and Transformation Plan aims, amongst other provisions, to promote women's ownership over assets. The National Policy on Women (1993) provides the framework for various interventions to level the playing field [2].

Ethiopia has a long history of land reform. The Derg regime (1974-1987) promoted "Land to the Tiller" [37]. Farmers had to demonstrate use through plowing, which was impossible for women to demonstrate given widespread cultural norms. As a consequence, married women typically lost access to land upon death of their husband or divorce. Women heads of households were generally reduced to sharecropping [38]. The First Stage Land Registration (FSLR), initiated in 1998-1999 in Tigray, enabled female household heads to obtain certificates in their name, but failed to provide for spouses in MHHs $[36,39,40]$. The Second Stage Land Registry (SSLR) i 2003 allowed spouses to receive land certificates in their name [40]. According to Holden and Tilahun [39], 90\% of FHHs hold land, $45 \%$ of women in MHHs do not hold a land certificate, and in $35 \%$ of MHHs, land is certified jointly. Mulema and Damtew [38] note, though, that land allocated to FHHs is often of poorer quality and distant from their homes. Even so, Holden and Tilahun [39] suggest that now that FHHs usually hold land title their productivity gains are relatively high, partly because many sharecrop. Today, land registration is ubiquitous across the country, but as suggested above, gender biases continue to skew land ownership. Our findings shed further light on these processes.

Access to labor and finance/credit also influence innovation and the amount of land farmers can cultivate [36]. In South Gondar, for example, there is little variation in land-holding size between MHHs and FHHs (0.907 MHH and 0.888 FHH). However, FHHs lack adult male labor, oxen, and capital to plow, and cultural norms forbid them from doing this themselves. Consequently, three-quarters of FHHs sharecrop compared to just 3.3\% of MHHs [30] (see also [41]). Similarly, the generally lower quality and quantity of productive resources controlled by FHHs tend to diminish their ability to obtain collateral [33,36] and, in turn, credit [29]. The ability to participate in revolving credit associations is often based on perceived wealth status and the capacity to contribute financially-they are not open to all [33]. 


\section{Materials and Methods}

This paper is based on data from eight community case studies in wheat- and maize-based systems in different regions of Ethiopia. Within this context, we primarily draw on data from interviews and focus group discussions (FGDs) with women. The case studies were part of GENNOVATE, a large-scale qualitative, comparative, and collaborative research initiative examining the interlinkages between gender norms, agency, and agricultural innovation. For detailed discussion of the methodology, and for the field instruments, see Petesch et al. [42,43], (see also www.gennovate.org).

\subsection{Sampling and Data Collection}

The study communities were selected according to purposive maximum diversity sampling guided by a $2 \times 2$ matrix with four variables: wide gender gaps or narrow gender gaps on one axis, and high or low economic dynamism on the other axis. Gender gaps were assessed in relation to school enrollments, women's mobility, and participation in household decision-making. Economic dynamism was assessed in relation to markets, infrastructure and services, transport and communication, and the quality of the local natural resource base.

The local field team (four women and four men) had strong local knowledge and local language proficiency. They worked closely with local conveners from the study communities to set up the sampling frame and identify study participants according to the sampling criteria for each instrument. In each community, fifteen research activities were conducted, all but one disaggregated by gender. This included six sex-specific FGDs with low-income women and men (aged 30 to 55), middle-income women and men (aged 25 to 50), and young women and men (aged 15 to 24); four semi-structured life-story interviews (two with women and two with men); and four semi-structured innovation trajectory interviews (two with women and two with men). In each research site, a community profile was conducted with female and male key informants. Further details and discussion related to the sampling are provided in Petesch et al. [42,43]. In total, 269 women and 268 men participated. No financial incentives were offered, but the focus group discussions, which took a long time, included a local coffee ceremony.

Given this paper's interest in how marital status contributes to shaping women's capacity to innovate in their livelihoods, we draw primarily on the subset of our data comprised of 16 innovation trajectory interviews and 16 life-story interviews across the cases. Innovation trajectory interviews were conducted with respondents known in their community for experimenting with new agricultural practices or related entrepreneurial initiatives. Life-story interviews were conducted with individuals who had been engaged directly in agriculture-related activities in the past 10 years, but who had experienced different wellbeing outcomes. While the classical ethnographic version of the life history method can be extensive and include multiple interview sessions, the life-story instrument applied here was conducted in one sitting and followed a standardized semi-structured interview guide with a focus on the last 10 years [43].

Both individual interviews opened with an exercise called the Ladder of Power and Freedom (Ladder). Respondents are asked to rate, on a scale from 1-5, their current ability to make important decisions in their lives, including about their working life and whether to start or end a relationship. A score of 1 represents very little decision-making power, while 5 represents the ability to make most major life decisions. The interviewee is then asked to think back and locate the step they were on 10 years ago and to reflect upon the reasons for change. We use the Ladder ratings as an indication of the respondent's self-perceived sense of agency. For innovators, the interview continued with questions centered on issues like: How does s/he learn about and try out, adopt, or adapt new things in her/his farming activities or related entrepreneurial enterprises? How does $\mathrm{s} / \mathrm{he}$ interact with wider institutional structures to push forward her/his agendas? How does s/he work with and negotiate gender norms in this process? Meanwhile, the life-story interviews were structured along three core topics: (i) occupational history, (ii) economic history, and (iii) psychosocial and cultural history. Table 1 provides an overview of the responses to the individual interviews. The data provided by life-story 
and innovator respondents are combined here and throughout the article. We bring in findings from women's FGDs and community profiles as relevant.

Table 1. Selected characteristics of the semi-structured interview sample (averages).

\begin{tabular}{lcc}
\hline Characteristics & Married (n = 13) & Single * $\left.^{*} \mathbf{n}=\mathbf{1 9}\right)$ \\
\hline Age & 40 & 44 \\
\hline Number of children & 6 & 5 \\
\hline Age youngest child & 7 & 12 \\
\hline Age oldest child & 22 & 26 \\
\hline Polygamy (currently, or if single, in past) & $38 \%$ & $42 \%$ \\
\hline Completed at least primary education & $38 \%$ & $21 \%$ \\
\hline Cropland owner & $54 \%$ & $79 \%$ \\
\hline Agricultural producer & $100 \%$ & $95 \%$ \\
\hline Shop owner & $46 \%$ & $21 \%$ \\
\hline Petty trader & $38 \%$ & $63 \%$ \\
\hline
\end{tabular}

* Eleven divorced, two separated, six widowed.

At the beginning of each data collection activity, facilitators read out an ethical statement. This explained the study's purpose, assured confidentiality, and informed study participants that they had the right to not answer questions and were free to end their participation at any time. All names of study participants and communities in this article are pseudonyms.

The analysis strategy was designed to enable systematic qualitative comparative analysis with procedures that rest on triangulation of data pertaining to the agentic capacities and livelihood experiences of women in male-headed households vis-à-vis women heading their own households. Following transcription, all data underwent a rigorous process of systematic content analysis and coding using Nvivo, a software supporting qualitative data analysis. A combination of variable-oriented analysis of the coded data to identify trends and patterns across contexts or groups with context-informed case-oriented analysis was then performed. This involved dozens of queries of the coded data, and additional systematic content analysis was conducted in Excel for the subsample of semi-structured interviews on topics that required deeper comparative analysis. Throughout the analysis, findings were consistently probed to further test and compare differences in the two groups of women upon which the paper focuses.

\subsection{The Study Communities}

The eight study villages are located in three regions of Ethiopia: Southern Nations, Nationalities, and Peoples' Region (SNNPR), Amhara, and Oromia. They are mainly populated by smallholder farmers. In addition to maize and/or wheat, producers cultivate a range of crops, including barley, teff, sorghum and khat, and diverse vegetables, and maintain some livestock. Data from the community profiles and FGDs suggest a large gender gap between the two cases from SNNPR (Southern Nations, Nationalities, and Peoples' Region), a somewhat smaller-though still high-gender gap in the four Oromia cases, and a relatively low gender gap in the two Amhara cases. For instance, girls in Hanawa (SNNPR) are reported to be unlikely to attend secondary school and are typically wed by age 15 . However, most young women in Badero (Amhara) attend secondary school and do not marry until age 19 or older. In six of the study villages, the young women's focus groups indicate that it is typical for them to marry younger than age 18, and in five villages, to have a child before this age. Gender-based (physical) violence was reported as a regular occurrence in seven of the eight cases. The numbers of FHHs vary. Key characteristics of the study communities are summarized in Table 2. 
Table 2. Overview of community case studies, Ethiopia.

\begin{tabular}{|c|c|c|c|}
\hline $\begin{array}{l}\text { Region, Village } \\
\text { (Pseudonym) }\end{array}$ & $\begin{array}{l}\text { Population } \\
\text { Sampling Frame }\end{array}$ & Main Crops and Livestock & Social Characteristics \\
\hline Amhara, Gobado & $\begin{array}{l}\text { 10,800 } \\
\text { Economic dynamism: High } \\
\text { Gender gaps: Low }\end{array}$ & $\begin{array}{l}\text { Wheat, fava bean, cattle, } \\
\text { sheep, poultry }\end{array}$ & $\begin{array}{l}\text { Ethnicity: } 100 \% \text { Amhara } \\
30 \% \text { FHH }\end{array}$ \\
\hline $\begin{array}{l}\text { Amhara, } \\
\text { Badero }\end{array}$ & $\begin{array}{l}4000 \\
\text { Economic dynamism: High } \\
\text { Gender gaps: Low }\end{array}$ & Barley, fava bean, wheat, peas & $\begin{array}{l}\text { Ethnicity: } 100 \% \text { Amhara } \\
\text { 17\% FHH }\end{array}$ \\
\hline $\begin{array}{l}\text { Oromia, } \\
\text { Chala }\end{array}$ & $\begin{array}{l}5652 \\
\text { Economic dynamism: High } \\
\text { Gender gaps: High }\end{array}$ & $\begin{array}{l}\text { Wheat, barley, peas, beans, oats, } \\
\text { sesame, maize, chickpea, potato, } \\
\text { carrot, beetroots, garlic, cabbage, } \\
\text { onion. Cows, oxen, horse, donkey, } \\
\text { sheep, and goats are common }\end{array}$ & $\begin{array}{l}\text { Ethnicity: } 75 \% \text { Oromo, } 20 \% \\
\text { Amhara, 5\% Gurage. } \\
\text { Religion: Orthodox Christian, } \\
\text { Protestant, Muslim } \\
\text { 25\% FHH }\end{array}$ \\
\hline $\begin{array}{l}\text { Oromia, } \\
\text { Akkela }\end{array}$ & $\begin{array}{l}3344 \\
\text { Economic dynamism: High } \\
\text { Gender gaps: High }\end{array}$ & $\begin{array}{l}\text { Wheat, barley, peas, beans, oats, } \\
\text { sesame, maize, chickpea, potato, } \\
\text { carrot, beetroots, garlic, cabbage, } \\
\text { onion. Cows, oxen, horse, donkey, } \\
\text { sheep, and goats are common }\end{array}$ & $\begin{array}{l}\text { Ethnicity: } 80 \% \text { Oromo, } 20 \% \text { Amhara } \\
\text { Religion: Orthodox Christian, } \\
\text { Protestant, Muslim } \\
10 \% \text { FHH }\end{array}$ \\
\hline $\begin{array}{l}\text { Oromia, } \\
\text { Nebele }\end{array}$ & $\begin{array}{l}6992 \\
\text { Economic dynamism: Low } \\
\text { Gender gaps: High }\end{array}$ & $\begin{array}{l}\text { Maize, wheat, barley, teff and } \\
\text { sorghum, carrot, beetroots, } \\
\text { and cabbage }\end{array}$ & $\begin{array}{l}\text { Ethnicity: Oromo: } 100 \% \\
\text { Religion: Muslim, Christian } \\
5 \% \text { FHH }\end{array}$ \\
\hline Oromia, Oromila & $\begin{array}{l}3000 \\
\text { Economic dynamism: Low } \\
\text { Gender gaps: High }\end{array}$ & $\begin{array}{l}\text { Maize, sorghum, wheat and teff, } \\
\text { avocado, banana, cabbage, beet } \\
\text { roots, potato, swiss chard, } \\
\text { and carrot }\end{array}$ & $\begin{array}{l}\text { Ethnicity: Oromo: } 95 \% \text {, Hadiya: } 1 \% \text {, } \\
\text { Guraghe: } 1 \% \\
\text { Religion: Majority Muslim } \\
5 \% \text { FHH }\end{array}$ \\
\hline SNNPR, Hanawa & $\begin{array}{l}2560 \\
\text { Economic dynamism: Low } \\
\text { Gender gaps: High }\end{array}$ & $\begin{array}{l}\text { Maize, inset, tomato, onion, carrot, } \\
\text { potato, cabbage, khat, pepper }\end{array}$ & $\begin{array}{l}\text { Ethnicity: Sidama: } 99 \% \text {, Welayita: } \\
\text { 1\% } \\
\text { Religion: Protestant, Muslim } \\
41 \% \text { FHH }\end{array}$ \\
\hline $\begin{array}{l}\text { SNNPR, } \\
\text { Wariso }\end{array}$ & $\begin{array}{l}9000 \\
\text { Economic dynamism: Low } \\
\text { Gender gaps: High }\end{array}$ & $\begin{array}{l}\text { Maize, beans, enset, sorghum, teff, } \\
\text { tomato, onion, carrot, potato, } \\
\text { cabbage, khat, pepper }\end{array}$ & $\begin{array}{l}\text { Ethnicity: Sidama: } 100 \% \\
\text { Religion: Protestant, small number } \\
\text { of Muslims } \\
13 \% \text { FHH }\end{array}$ \\
\hline
\end{tabular}

\section{Results}

We first highlight women's innovative practices in the study communities. We then present findings related to women's access to resources with particular emphasis on land, labor, and credit. This is followed by an examination of factors that affect women's agency. The section concludes with a presentation of women's achievements in mobilizing resources and exercising agency. Though our findings are not statistically representative, we use figures to highlight differences and commonalities between married and single women.

\subsection{Women's Agricultural Innovation Experiences}

Respondents were encouraged to discuss their agricultural and other innovations during the interviews. However, they were not systematically asked how many innovations they had introduced or adopted. This means that some innovations may not have been captured. Nevertheless, it is useful to work with the data provided by the women themselves, as this suggests which innovations were most salient to them. Table 3 provides an overview of the types of innovations married and single women in the interview sample mentioned that they had engaged with. Many of them mentioned several things; thus, the totals for both categories add up to more than $100 \%$. The table suggests that a larger percentage of single women have tried out improved wheat varieties compared to the married women, while the latter, relatively speaking, appear to have more experience with improved maize than single women. Married and single women are roughly equally likely to have introduced other crops and agronomic practices. 
Table 3. Innovations claimed by married and single women (32 semi-structured interviews).

\begin{tabular}{lcc}
\hline Type of Innovation & Married (13) & Single (19) \\
\hline Improved wheat & $38 \%$ & $58 \%$ \\
Improved maize & $46 \%$ & $37 \%$ \\
Other crops & $77 \%$ & $74 \%$ \\
Agronomic practices & $62 \%$ & $68 \%$ \\
Other (e.g., animals) & $54 \%$ & $26 \%$ \\
\hline
\end{tabular}

When asked to reflect on what factors support women's capacity to innovate, members of the women's middle-income FGDs most frequently mentioned access to information and learning opportunities, followed by finance and other productive resources. Self-confidence, willingness to work hard, commitment, and courage were mentioned by many as personal characteristics that support innovation capacity. Married and single women who were recognized by the wider community as being successful innovators (respondents to the innovation trajectory interviews) perceived their own determination to succeed, followed by supportive family members, to be critical success factors. Turning to factors that hinder women from innovating, middle-income women FGD respondents pointed out lack of capital and generalized poverty, followed by lack of support from family members, having large families, and limited support for women's groups. A respondent in a middle-income FGD in Chala summarized constraints as being "A lack of space [facilitator: What do you mean?]. I mean physical space to try the innovation-a space where you do the new thing, and also lack of opportunity to decide to do your own thing. If somebody else is deciding for you or if you are waiting for them to decide for you, then it may not happen."

\subsection{Women's Access to Resources}

\subsubsection{Gendered Access to Land}

As discussed above, land registration is now present across Ethiopia, yet gender biases continue to skew land ownership. Our data shed further light on these processes.

Our sample is biased towards acknowledged innovators and is not representative of women holding land titles jointly, or individually, in the study communities. Figure 1 shows the proportions of the women interviewees holding land certificates in their own name, or jointly with their spouse, across all eight communities. The size of their holdings ranges from $1 / 4$ to 2 hectares. Sixteen single women have land titles. This compares with seven married women with their own or joint certificates. Several married women access plots through husbands, but this land is not registered in their name. One married woman obtained land through a government redistribution program for newlyweds. Two married women rent or sharecrop land, as does one single woman. Three single and six married women do not have land titles. Most married women said that they work on their husbands' land. Two single women stated that their husbands gave them land when they separated, but the land remains in their husband's name. One single and one married woman own and rent land, and a married woman in a polygamous relationship rents land because she does not have any land herself. In our dataset, therefore, relatively more married than single women do not have land certificates. This accords, roughly, with the national data described in the literature.

Our data show, however, that although Ethiopian legislation provides women with rights to land upon dissolution of a marriage, this is far from certain. Single women reported that securing property claims requires protracted negotiations with former husbands, in-laws, village elders, or in the courts. One separated woman reported that, "At first, my husband refused to give me land and he took all the cattle. It took me more than two years to get a portion of the land from him through a long negotiation through the elders" (age 48, Oromila). Other single women reported obtaining land through the local government administration (kebele), or because the land was a shared family asset, inheriting land 
from grandparents, and in one case, a woman who had entered a forced marriage was given land by her father when she left this marriage.

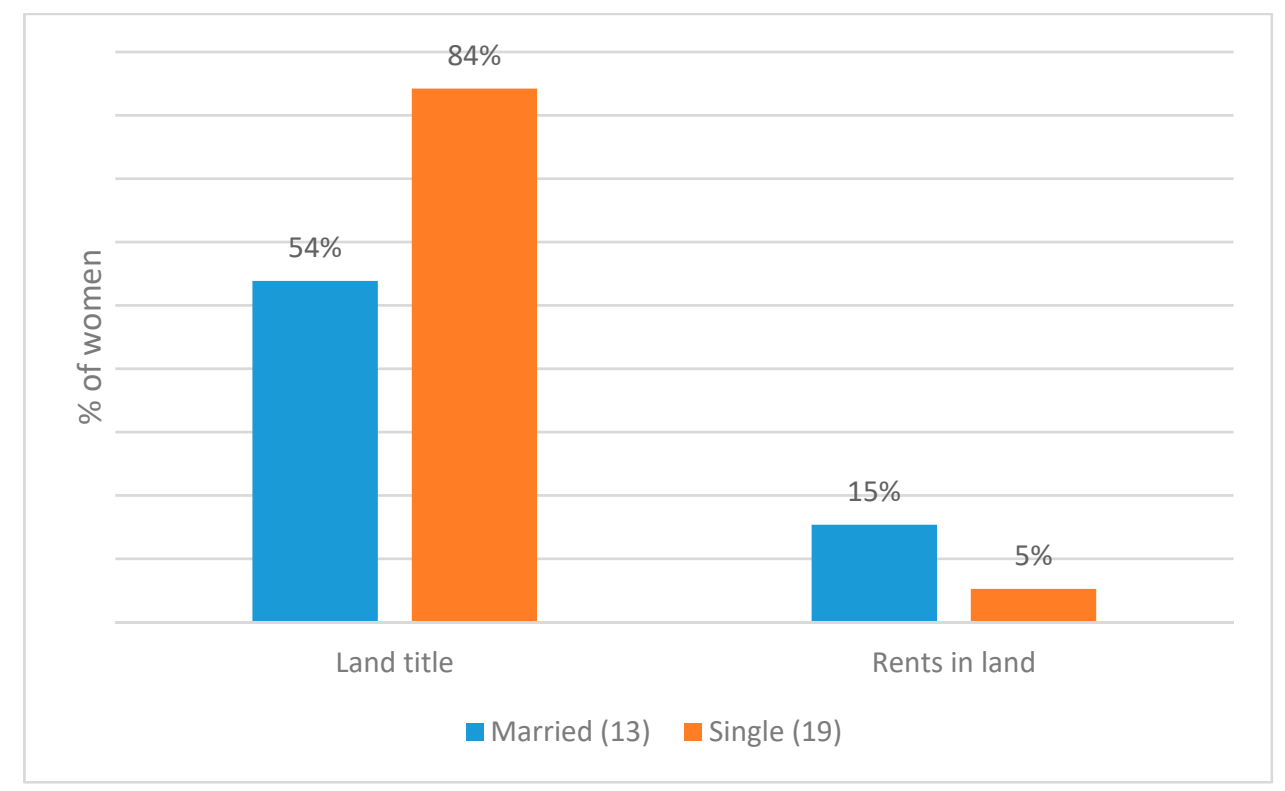

Figure 1. Gendered access to land (32 semi-structured interviews).

A 39-year-old widow (Chala) described being stabbed and hospitalized for six months for refusing a proposal to marry a man from her husband's kin, which would have resulted in loss of control over her land. She further resisted her son's claims on her two hectares. Other women have compromised. A 54-year-old woman (Oromila) explained that when she separated from her husband over his taking a third wife, she received three timads ( 1 timad $=$ approximately 0.25 ha). She passed one-third to her son, as she considered this a cultural obligation. A third woman (39, Chala) reported passing her land to her three children to protect it from her in-laws. In some cases, single women respondents failed in their attempts to obtain land. A widow in Hanawa (aged 42) was put under pressure to marry her brother-in-law so the in-laws could maintain control over her land. She eventually surrendered the land to her sons-and thus her husband's lineage—and now rents a tiny plot. The three separated women who reported being without land titles have been provided with usage of a small plot by their ex-husbands, who nevertheless remain the owners of this land. Relations are not inevitably hostile, though. "My late husband's younger brother encouraged me and supported me by sending his family to my farm when my children were too young to work", said a woman now aged 40 (Nebele). They later married.

It is rare for married women to inherit land, and it can be difficult for them to keep it. One such woman (33, Wariso) reported that her mother provided her with some land after her father died. However, her father's relatives pressured her mother to pass this land to them, rather than her daughter. According to the local culture, the respondent explained, only boys inherit land.

Community profile respondents in Hanawa reported that women generally do not seek legal support despite national legislation. Due to a fear of violence from the in-laws, "no one, not even her siblings, will plow [a woman's] land." Indeed, it was only in the two communities in Amhara that statutory inheritance legislation is widely respected, in contrast to Oromia and SNNPR, where customary norms appear to be widely followed. In these communities, it was reported that women who take spouses, brothers, or in-laws to court often become outcasts.

Overall, most single women respondents testified to considerable struggles to claim, and then maintain control, over land when their marriages ended. They attributed this to the persistence of customary practices and norms privileging men's claims on land and other property in the family. 
Men are much more likely to inherit land than women, and women can be placed under immense pressure from their husbands' relatives to relinquish land to them outright, or through attempts to force a widow or separated woman to marry into the husband's kin.

\subsubsection{Gendered Access to Labor}

Meeting labor needs is a key challenge for many smallholders. Figure 2 shows how the women interviewees seek to address this. While some single women sharecrop, hired laborers are used by both married and single women. Some single women reported, though, that men they sharecrop with, or hire, do not necessarily do as they wish. One woman (45, single, Chala) explained, "I am helpless when it comes to labor. I try on my own. The farmer I am sharecropping with agreed to help if I am not row planting, so I never tried the proper cultivation processes." Another woman in Chala $(55$, single) said she wanted to apply row planting because it is "very economical in terms of fertilizer and seed usage. However, it is difficult for female-headed households who have no male labor. If she hires labor, then he will be the one who decides on what should be done." This comment suggests that, whilst access to labor is a constraint, the difficulties single women have in setting out demands and expectations vis-à-vis male employees can be equally inhibiting, particularly with respect to innovation.

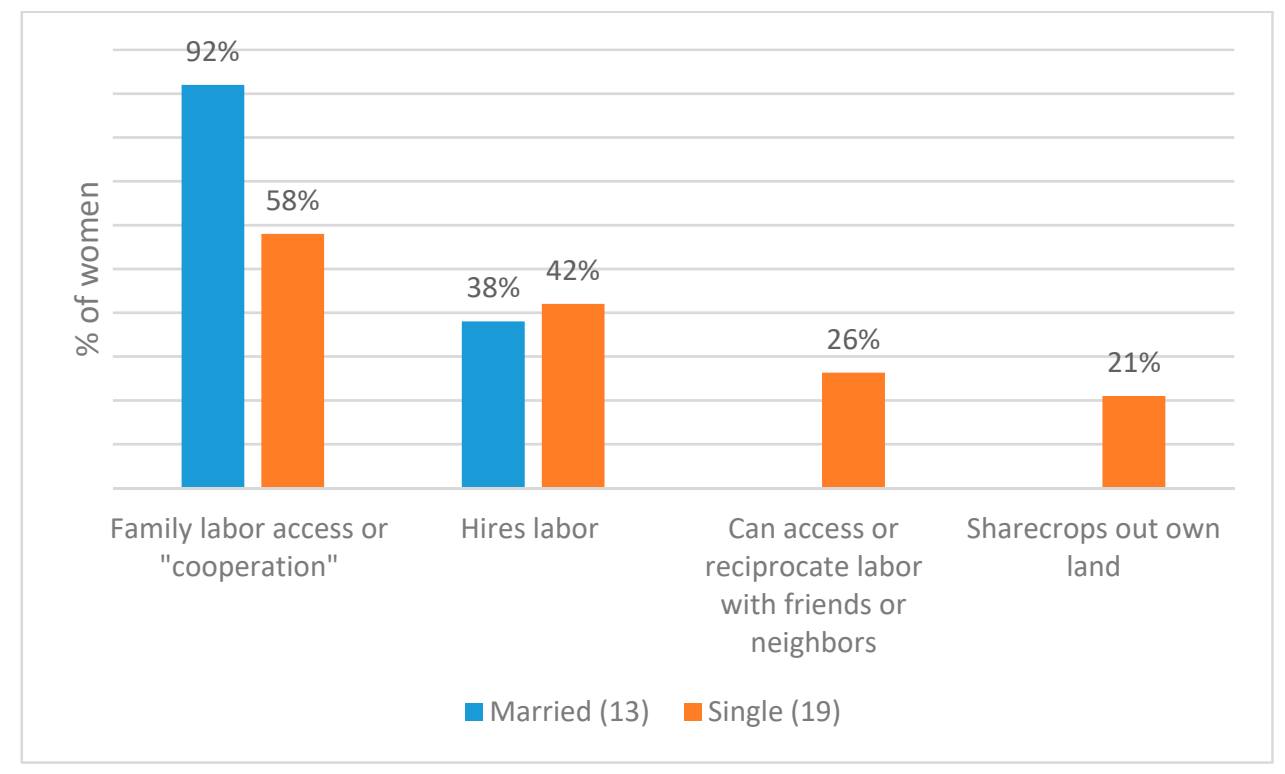

Figure 2. Women's access to labor (32 semi-structured interviews).

The majority of both married and single women reported accessing family labor, including husbands and children in the case of married women, and primarily children in the case of single women. Most single women stated that they generally face difficulties obtaining sufficient labor. A divorced woman in Amhara (50, Gobado) said that her problems are always "in relation to labor. As I do not have oxen, I am always challenged with oxen and labor." Five single women reported engaging in reciprocal labor (debo) schemes with friends or neighbors-married women did not. A single woman in Oromia (54, Oromila) explained that at harvest time: "My children and the neighbors, through debo, are always at my disposal. My son is there to engage in reciprocal labor with my neighbors. When there is a gap, I always hire day laborers." However, a few single women say that they do not have labor to reciprocate, due to which they cannot make use of debo. As a result, they need to hire labor, which makes farming more expensive. It is not clear whether married women hire labor themselves, whether this is a shared expense (it is in some cases), or whether they are referring to their husbands hiring labor. 


\subsubsection{Gendered Access to Credit}

Our findings show that approximately two-thirds of married women (8 out of 13) and three-quarters of single women (14 out of 19) access diverse forms of local savings or credit schemes. Generally, they are members of village-level savings groups called "equb". Credit is taken out for many reasons, including emergencies. Some use credit specifically to try out innovations; for example, a married woman (44, Akkela, Amhara) took out credit to purchase improved cattle and a cart, and another married woman took out credit to expand her poultry farm. A widow (39, Chala) took out credit initially to finance row planting, and then the following year, "I hired labor, and bought the fertilizer and everything needed for the row planting with the credit I took. I returned the money the next year. I did not produce as I expected, but the money was enough to pay up the loan, the tax, and some was left for next year's expenses." In general, though, women appeared reluctant to finance innovation through credit.

\subsection{Women's Agency}

We assessed women's ability to take a range of meaningful decisions, including in relation to productive resources and income. We also explored the degree to which women expressed agentic traits, such as self-confidence, determination to succeed, and risk-taking. We first present findings reflecting women's own assessments of their current agency, drawing on the individual interviews, followed by how this has changed over time, using data from individual interviews and middle-income FGDs.

\subsubsection{Women's Current Agency}

Most single women in the interview sample experienced strong agency in several ways in relation to production decisions as well as the management of their produce and income (Figure 3). Nearly all single respondents say they became the main decision-maker following separation or death of their husband. A woman in Oromia (54, Oromila), for example, mentions that she became the household head after divorcing her husband: "Since my husband left me with the land, oxen, and a few small animals, I survived with the help of my sons. I became my own boss. My kids respect my decision. I am even accepted by the community, and sometimes I am asked to act as a Shimagle [an elder]." This woman uses improved seeds, fertilizer, and pesticides. However, though many single women experience strong agency, they do not necessarily feel secure. One divorced woman (45, Chala) said, "I produce Arekie [liquor] once a week, and every single day I work on the ingredients. I then carry it to the people who buy from me. I am afraid to sell it at home because I do not have any protection. If I could sell it at home, I could profit more."

However, single women also discussed several constraints on their decision-making capacity in other regards. These primarily relate to family members, including ex-husbands, siblings, parents, and, above all, older sons, attempting to assert authority over them. For instance, a divorced woman in Amhara (39, Badero) said she decides whether to hire labor and sell or buy poultry and large consumer durables, but is required to negotiate with her siblings, with whom she lives, should she want to sell land, large livestock, and farm equipment. Another divorced woman in Amhara (29, Gobado) who felt she had low agency explained that, a decade ago, she was fully under the control of her parents. She then experienced the "imposition" of her husband. Following divorce, she lives with her parents and has to take their opinions into account. A separated woman (37, Gobado) also experiences very low agency, explaining, "My decision-making capacity and freedom have declined over the years as I have nothing to decide on. The land belongs to my husband. The house belongs to my husband. I have no say, I am only allowed to use it. When he wants, he may evict me anytime." 


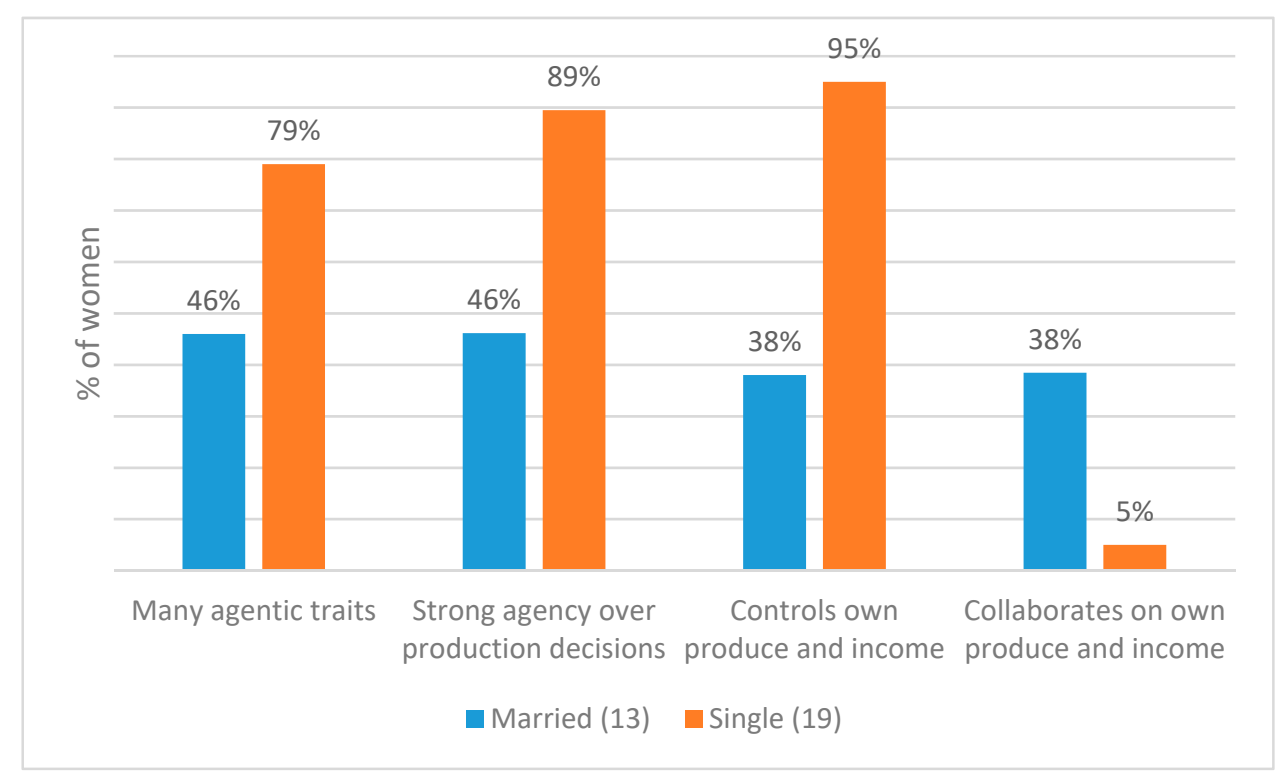

Figure 3. Dimensions of women's agency (32 semi-structured interviews).

For several single women, older sons represent the most significant challenge to their decision-making capacity. Cultural norms favor the authority of older sons over their mothers, and it can be very difficult for single mothers to extricate themselves from their sons' attempts to control them. One woman (39, Chala) said, "Since my husband died, I decided everything until my son started to act as if he is the owner of the house. I struggled a lot for many reasons, I even gave him his portion of the land, but he still tries to influence my decisions. He is doing this because he thinks he owns me. Despite this situation, I am deciding for myself." Another woman explained, (54, Oromila), "Mostly sons replace their father's place in a single female household. However, I never allow them. My elder son has tried to do so for a long time. He got married and I sent him out with his own land and told him to mind his own business. [Facilitator: How did he react?] It was tough at first, but now, all my children have accepted my position. In addition, they have no reason to disrespect me, since I have not married on their father's land." All single women, bar one, fully control their own income, and they report valuing no longer being financially dependent on their husbands. For one woman in Amhara (51, Gobado), her independence is so important that she declines financial assistance from her children. "I use my own money. I prefer my children to live happily with their families. Sometimes they insist on helping me, but I feel alive when I use my own resources."

Among the 13 married women, five testified to independently managing their economic initiatives, five cooperate closely with their partners, and three have no control. Some married women consider joint decision-making to be an indicator of strong agency (unlike single women, who consider sole decision-making to be such an indicator). Women who feel they have moderate to low agency say their husbands make almost all decisions. A couple of married women make nearly all decisions because their husbands travel regularly. One woman (33, Wariso) added nuance by saying "It's both me and my husband, but I am the one who helped him to see the world differently [Facilitator. How?] In this area, men never allow women to work and earn money, but in my case, he accepted the fact that I can also contribute to the family income." The diversity of her livelihood activities suggests that she achieves this through considerable innovation. On the half hectare that she inherited, she grows khat, pepper, haricot bean, enset (false banana), and IMVs. She also helps her husband with his maize and khat production, and she has used her proceeds over the years to open a hair salon and grocery. A woman in Amhara (40, Gobado) discusses with her husband on which inputs to buy and whether to hire labor, and finances this from joint savings. Overall, married women are generally able to make independent decisions on some important matters, but must consult closely with their spouses on others. Women everywhere are generally free to sell small quantities of butter, eggs, and vegetables 
in local markets and to manage petty businesses. Husbands (unless they are incapacitated through illness) typically manage overall household finances and decisions around large expenditures.

If a husband does not support his wife when she wants to innovate, she is likely to fail. One single woman explained (45, Wariso), "My husband was the one who produced on the land, managed the expenses and the production for consumption and market. When I decided to try [to innovate] on the land he gave me, he refused and said 'how come you want to be involved on the farm like a man?'. For this reason, he quit supporting me and ordered my son not to support me. He then totally focused on his current family [speaks sadly and cries]. Though I didn't quit and tried the new practices by myself. No, I am not ok." This woman found that her wish to innovate also brought her into conflict with her neighbors. She recounted that, "They are not happy with my accomplishment because they assume that I will be a bad example for other wives."

\subsubsection{Trends in Women's Agency over Time}

Interviewees were asked to consider their present agency by grading themselves on the Ladder of Power and Freedom. They were then asked to consider their agency ten years earlier (Figure 4). Married women generally rated themselves at step 3 currently and in the past. By contrast, single women observed a two-step jump to step 4 . The ratings are averages and conceal some variation between women. Some married women registered an improvement in their agency. Several attributed this to gaining a more cooperative relationship with their spouse. In some cases, this was due, at least in part, to a strengthening in their economic contributions to the household. Other married women explained their higher ratings by saying that they now have a greater awareness of their rights. A 40-year-old married woman (Chala) said, "The man will never allow women to administer or decide on everything. These days, we have reached a fair degree of decision-making, but it is still difficult for the woman to decide on everything." Nevertheless, most married women experienced no change.

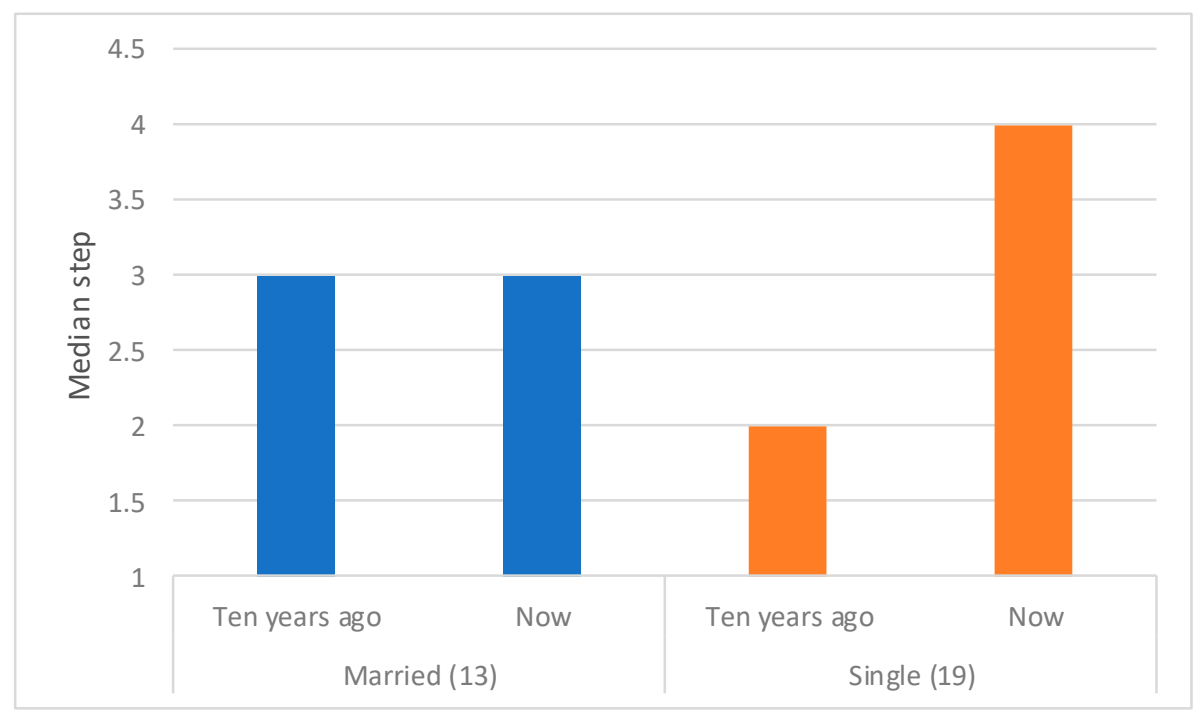

Figure 4. Median perceived level of agency on a five-step ladder: ten years ago and now (32 semi-structured interviews).

Overall, a key factor for how women assessed their position on the Ladder of Power and Freedom related to their status in the household and whether that had changed in the last decade. Divorce, separation, or the death of the husband mark key turning points for many women in being able to express their agency as they wish. Even so, many single interviewees reported taking years to establish effective agency and the capacity to innovate. At first, the majority, regardless of how they became single, mention struggling with stigma, violence, or impoverishment. However, over time, some respondents were able to innovate to some degree. A 43-year-old woman (Hanawa) testified that 
she fell from step 4 to step 3 after separating from her husband: "For many years, my husband and I lived in harmony. We used to decide together. Our entire aim was to grow, and so we were working hard. However, two years ago, he brought a new wife without asking me." She did not accept this and, following separation, now makes, "all decisions regarding my household. I became encouraged and motivated once I tried to farm by myself. That was why I worked hard, opened a small tea shop, bought a donkey cart, and have a vegetable garden." Even so, her autonomy is limited. Her plot remains in her husband's hands, and they sharecrop together. Among the six widowed respondents, one 48-year-old (Badero) climbed from step 2 to step 4 "because after my husband's death, I am the one who produces, generates income, and deals with any social affairs. Ten years ago, I was under my husband. He was the breadwinner and he consulted me on major issues, but ultimately, he was the one who made all the decisions." After his death, she became a full-time farmer. She hired workers and experimented with row planting and improved wheat seed. A second widow (remarried and subsequently divorced) recounted a more complex story. After her first husband's death, her brotherin- law plowed the land on a sharecropping basis, "But later, he pressured me to get married. After a while, I succumbed and married him. I stopped working for a while when I was living with him and after I gave birth to his child. It is my divorce [from him] which gave me my freedom to work. Without my decision to be set free from that marriage, I would not be able to be here. If I was still married to my brother in-law, I would have killed myself. The fact that I gave up their land set me free, and with that freedom, now I can do anything I want" (46, Hanawa).

\subsubsection{Associations between Gender-Based Violence, Agency, and Capacity to Innovate}

As suggested by the foregoing narratives, gender-based violence (GBV) plays a significant role in the lives of many respondents. GBV comes in the form of physical violence or psychological violence: threats, forced marriage for widows to ensure that land remains within the deceased husband's lineage, name-calling, and, indeed, the fear of physical violence should women transgress cultural norms around innovating, buying, or selling or women's mobility.

One single woman $(45$, Chala) reported being beaten after she started to buy and sell wheat. A widow in Sidama (42, Hanawa) reported that her in-laws spent a lot of time forcing her to remarry in order to get back their land. She attempted to innovate, but in the end, felt compelled to give her land to her son. Now she farms a tiny plot and says that her spirit is broken.

A married woman asked for divorce because she could not tolerate being unable to innovate. She said, "I was married 10 years ago, and I used to buy and sell wheat. This created a lot of problems with my husband. He was drinking and beating me. I could not stand it anymore, so I asked for divorce. When I did that, I thought that he may kill me. Knowing I have no one, I decided to start selling sugar cane in the nearby market and to get into 'equb', which helped me to get some money" (45, Chala). Another woman (39, Badero) reported that, “When I was with my husband, I couldn't even dress as I wanted or go to places ... He used to beat me and harasses me. He was drinking and ... our life became miserable. Though we had land, we were very poor." Following divorce, this woman innovated on her land and is now able to send all her children to school and have food all year around, and she has built an improved house.

In some cases, the fear of violence alone prevents women's innovations. For instance, women are rarely permitted to undertake large transactions. In Wariso (SNNPR), an 18-year-old petty trader remarked that "Women never take big animals or lots of grains to the market. Not a single woman has tried it because, if she does, there would be consequences, such as a beating or divorce."

Name-calling and marginalization are another issue for women innovators. A widow (48, Badero, Amhara) recalled that, "Some women used to call me names, especially when my husband was alive, because I was working hard and was also actively participating in social affairs. They used to say "Yeset asarash Yewend asfetay" [a woman leading the farm and a man doing the weaving, i.e., both out of place and inefficient]. They said this because I was leading the household, the shop, the farm, etc. Gradually, however, they started to learn from me, so this has stopped now." 
Attending extension meetings, visiting lead farmers, and selling and buying at markets and shops are all important to women's ability to make money and to innovate. Respondents in young women's FGDs indicated that relative mobility differs among women according to age and marital status. In most sites, a young woman walking on her own risks harassment and sometimes assault and rape. Married women generally experience higher mobility. For instance, whilst young women in Nebele are not expected to visit the market on their own, a married woman is "protected because she has a husband. And if anyone touches her, that would be a big issue" (young women FGD, Nebele). Even so, married women are generally expected to be back in their home before their husbands arrive at the end of the day in order to avoid a beating or, potentially, abandonment.

Single women without an adult man in their home are afforded more mobility and find it easier to participate in meetings. However, in some sites, respondents noted risks of rape, violence, and theft for women who live without an adult male. Finally, quite apart from direct threats to their person, women respondents generally remarked that their ability to maximize the mobility that they do have is circumscribed by heavy workloads, lack of time, and limited transport.

\subsection{Women's Achievements (Outcomes)}

To assess the trends in terms of economic outcomes of the women in the interview sample, each interview was categorized according to whether their overall experience depicted accumulation of assets, limited accumulation, or declining production and vulnerability. Altogether, as shown in Figure 5, we find that married women accumulate relatively more resources $(62 \%)$ than single women $(42 \%)$. However, this is more likely at the household than individual level, since, as the data above demonstrate, women risk losing land and other resources when a marriage is dissolved. A relatively larger percentage $(42 \%)$ of single women than married women $(31 \%)$ demonstrate limited accumulation of resources, and a notable share of the single women $(16 \%)$ see production declining and feel very vulnerable. A married woman in Wariso (33) said, "We saved the money from the maize sale to build a house, because we were living in my younger sister's house. Our life has changed: I am able to buy the equipment for my hair salon, and we eat from year to year without any problem." In comparison, a divorced woman (37, Hanawa) says that she is getting by with lots of difficulties: "My biggest problem is not related to the maize. Rather, it relates to the lack of oxen to farm with, and I am also challenged with labor, as my children have their own house now ... The other problem is the lack of rain."

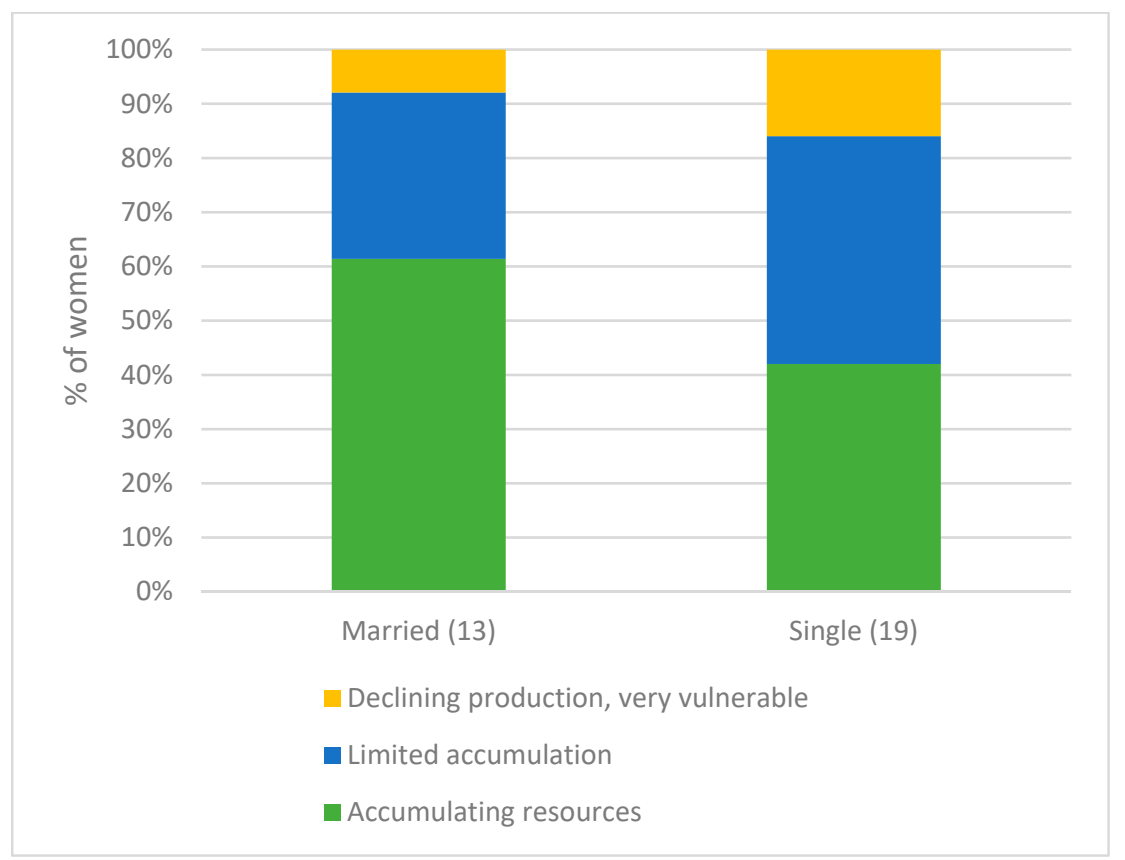

Figure 5. Women's assessments of their achievements (32 semi-structured interviews). 
Some married women made explicit links between purchasing or receiving land through redistribution, collaborative decision-making with their spouse, strengthened innovation capacity, and benefits. A woman (aged 45, Oromila) and her spouse obtained 1.75 hectares of jointly titled redistributed land. The couple plan the farm together. The respondent reported that she tested row planting in her kitchen garden, taught this to her husband, and they then applied this new practice to their cropland. Many married women signaled that building a house was the key indicator of success for them. Single women who are accumulating resources also associated their success with innovation. One divorced woman (54, Oromila) noted that, with the initial help of her sons, she was able to innovate by buying fertilizer, improved seeds, and pesticides. Whereas her husband previously owned land and livestock and made all decisions around them, now she does. A widow (aged 45) explained that by applying innovations, she produced more, sold more, and expanded her business. She supports herself and her seven children, opened a small cafeteria, and bought cattle.

\section{Discussion}

In this article, we explored the ways in which marital status influences the capacity of smallholder women to innovate specifically in agriculture and more broadly in their lives. We used Kabeer's [16] framework to examine our fieldwork data along two main axes, (i) access to resources, and (ii) agency, and we examined the outcomes that arose from the systemic working of these two factors.

Turning first to resources, our review of the literature suggested that governmental attempts to ensure gender equity in land distribution according to the provisions of the law were highly promising. Some studies suggest that the majority of female-headed households now have land in their name, and that many married women now hold joint titles with their husbands [39]. Our results cast these findings in a more critical light, strongly suggesting that pre-existing norms continue to shape women's ability to obtain and hold land titles. Women who attempt to claim land often face lengthy battles with their husband's kin, they may have to negotiate with traditional elders or face their husband's family in the courts. It is particularly notable that widows or separated women can be placed under significant pressure to remarry into their husband's lineage. Whereas during the marriage, they had accessed land through their husband, now, the kin seek to exercise their claim by exercising control over the woman's body and over her agency. Women's land rights are further contested by sons. Some, though not all, of the women who succeed in their land claims become outcasts.

The literature review also suggested that the conceptualization of the farmer in Ethiopia as male effectively makes invisible the contributions that women make across productive and post-harvest tasks in agriculture. Furthermore, the close identification of men with core agricultural tasks, particularly plowing, places single women under significant pressure to secure adult male labor to conduct these tasks. Our findings are in line with the literature review in that single women clearly find it difficult to source adult male labor. This drives some to sharecropping arrangements on their land. Others manage through reciprocal labor arrangements or by working with their children. We find that when single women hire male labor or try to manage male sharecroppers on the land, their ability to direct men can be restricted. This presumably relates back to the perception of men as "real farmers" and perhaps a wider scorning of women as not having a legitimate right to express their voices. There is an indication of such processes in Farnworth et al. [31]. We also find that married women face fewer labor constraints. This is because the farm, as a whole, has access to adult male labor, and some women work with their children.

Regarding women's ability to exercise agency, the literature review suggests that in some married households, decision-making is joint, and that should disagreement arise, the man is the "final" decision-maker. In other households, men make most decisions. We echo these findings, noting that married women exercise quite a lot of autonomy with respect to small daily decisions, but that men make significant decisions around resources, expenditure, and anything involving large sums of money. More collaborative households foster the ability of women to innovate. In those marriages where decision-making is strongly dominated by men, innovation seems much more difficult. Several 
single women left marriages where husbands wanted to exercise full decision-making power, or where men became physically violent towards them. For many single women, departure allows them to exercise greater control over their lives, and this includes decision-making around whether or not to try something new. However, single women also report attempts by others to deny their agency, particularly by older sons. An interesting finding is that, on average, married women generally do not find that their decision-making power increases over time. This contrasts with wider research data; for example, a study on the degree of female autonomy over their own health care found that older women have more decision-making power [44]. One issue we did not investigate or analyze sufficiently was the age of women upon marriage and whether this had a bearing on their existing and later decision-making capacity. Large numbers of women marry as children or adolescents in Ethiopia, although this has long been prohibited by national legislation [45]. Chuta [46] points out that such young women become wives and mothers before achieving a high level of education and economic independence, and argues that this contributes directly to reducing their personal bargaining power. Resources, Chuta [46] (p. 31) contends, are less important to women's bargaining power than the fact that decisions at the household level involve multiple actors, including parents and husbands-as well as norms. By this, she means that norms constitute women as dependents and prescribe a range of appropriate behaviors. Women have to bargain with individuals and, in a very real sense, with norms themselves.

The close association of the term farmer with men is not confirmed by our data, which indicates that all women respondents are comfortable in their skin as farmers. For the vast majority of them, farming is their livelihood, and they think, plan, purchase inputs, produce, and sell accordingly. Some women are more successful than others for the reasons we describe, but all our interview respondents see themselves as innovators. FGD respondents were also readily able to discuss their lives as farmers-and key informants in all study sites had no difficulty in locating women innovators. At the same time, our data do show, on occasion, that husbands actively deny women this identity.

The literature review suggested that women become single for any number of reasons. We did not investigate these processes in depth, but our sample comprised widowed and separated women. The data indicate that these women are engaged in all kinds of relationships with their ex-husbands, their kin, their own parents, and their children, and that these relationships have a strong bearing upon their ability to access resources and express agency. Female-headed households thus exist along a complex continuum and cannot be considered a bounded "household typology" with uniform characteristics. Drawing upon Chuta's (2017) [46] comment above, we also note how strongly cultural norms configure relationships. Women indeed negotiate with individuals-who themselves are configured by cultural norms-as well as patriarchy expressed in cultural norms [47]. In addition, some single women seem to trade off achieving autonomy with respect to resources and agency, with an acceptance of marginalization. Using data from Oromia, Farnworth et al. [31] found that whilst both women and men innovators face considerable challenges, women innovators, in particular, are precariously located 'outsiders within,' negotiating carefully between norm and sanction, and our data broadly support this.

We found Kabeer's framework (Resources-Agency-Achievements) [16] to be very useful. The approach permitted synergies between resources like land and labor, as well as the agency required to govern them, to become clearer. Of these synergies, the most obvious negative synergy is gender-based violence. This seems to permeate and to structure how women are able to relate to resources and their ability to express their agency over those resources, and then, in turn, to translate both of these into meaningful outcomes, or achievements. Gender-based violence may be expressed physically, by forcing women to marry, or through cat-calling and marginalization. Together, these constitute a set of mechanisms for restricting women's agency, for restricting their claims to land, or for preventing them from innovating. Our data show that some women fight, but eventually succumb and give up. Others fight and succeed. Married women are caught in relationships characterized by 
submission or collaboration. Collaborative relationships remain male-dominated, but women in such relationships appear able to achieve quite a lot.

\section{Conclusions}

In this study, we set out to explore how marital status influences the capacity of poor rural women in Ethiopia to innovate in agriculture, and more broadly in their lives. Overall, we find that whilst married women in acknowledged MHHs may experience a number of the preconditions for exercising agency (as per Kabeer [16]), their capacity to translate these preconditions effectively into actual livelihood innovations is, in many cases, constrained due to the limited ability to make decisions and act upon them. In contrast, single women leading their own households can be more likely to experience agency, but often lack the means (or preconditions, ibid.) to realize it. Through a grounded analysis, our study contributes to the literature by shining a light on how processes of marginalization and exclusion-inclusion affect different women in diverse ways, and specifically how marital status, intra-household relations, and dynamics of gender-based violence influence poor women's ability to innovate in their rural livelihoods.

Our findings have important development implications. One is that methodologies, such as household methodologies and couple approaches that support collaborative decision-making in married-and single-households, could be very useful, including as vehicles for reducing gender-based violence and for more gender-transformative agricultural development. Such methodologies can foster good relationships as well as promote the ability of women and men to innovate through critical reflection and inbuilt livelihood planning tools. As part of implementation, it is essential to get traditional authorities and other opinion formers on board, so these methodologies can provide a helpful nudge to change sociocultural norms. The Transformative Household was developed in Ethiopia [48,49], and there are others, such as the Gender Action Learning System (GALS), which has been rolled out in several countries [50,51]. Another widely used methodology in Ethiopia is termed "community conversations" [52], which engages women and men in critical dialogues around cultural norms and deciding for themselves on how to act.

Across various levels related to policy and programming, there is a need to dissociate the harmful institutionalized feedback loop between men, the plow, the notion of the farmer, and the ability to cultivate land. To break down this conceptual lock-in [53], interventions, whether related to mechanizing agricultural tasks or other agronomic practices and measures, should include women as well as men from the very beginning and at all steps. The Government of Ethiopia has already introduced considerable legislation to make targeting of women, whether as single women leading their own households or women within male-headed households, fully legitimate, in accordance with national development plans.

Our findings also stress the importance of strengthening community-led mediation processes in relation to land titling. Working with respected elders and other bodies to help them understand and then equitably implement national legislation is essential. Women in male-headed households and single women upon dissolution of a marriage need the security of having their land in their own name.

Similarly, initiatives to tackle gender-based violence in all its forms, including when exercised by women against men or other women, as well as by men against women, is a pressing need. Again, this requires community-managed initiatives.

Finally — and particularly sobering for researchers and development practitioners—our findings suggest that merely counting how many women have land certificates and registering a high tally are insufficient grounds for rejoicing. It is key to unpack whether women really have authority over their land and can actually use it.

We conclude by urging for further research on associations between women's resources, their agency, and their achievements. 
Author Contributions: Conceptualization, L.B., C.R.F., and P.P.; methodology, L.B. and P.P.; software, P.P.; validation, M.H.; formal analysis, L.B., C.R.F., P.P., and L.R.; investigation, C.R.F. and M.H.; resources, L.B.; data curation, L.B. and P.P.; writing-original draft preparation, L.B., C.R.F., and P.P.; writing—review and editing, L.B., C.R.F., P.P., and L.R.; visualization, P.P. and L.R.; supervision, L.B.; project administration, L.B.; funding acquisition, L.B. All authors have read and agreed to the published version of the manuscript.

Funding: This research was funded by the Bill and Melinda Gates Foundation, grant number OPP1134630, as well as the CGIAR Research Program on WHEAT. The development of the research design and the data collection were furthermore supported by the CGIAR Gender and Agricultural Research Network, the World Bank, the governments of Mexico and Germany, and the CGIAR Research Programs on Wheat and Maize.

Acknowledgments: We warmly thank the women and men farmers who participated in this research and generously shared their time and views, as well as all the members of the two data collection teams in Ethiopia and the data coding team. The views expressed in the article are those of the authors and not of any organization.

Conflicts of Interest: The authors declare no conflict of interest.

\section{References}

1. World Economic Forum. Global Gender Gap Report 2020; World Economic Forum: Geneva, Switzerland, 2019.

2. Teshome, A. How the Gender Equality Strategy for Ethiopia's Agriculture Sector Can Improve Outcomes for All; Technical Brief for the Agriculture Knowledge, Learning, Documentation and Policy (AKLDP) Project: Addis Ababa, Ethiopia, July 2018.

3. Mulema, A.A.; Jogo, W.; Damtew, E.; Mekonnen, K.; Thorne, P. Women farmers' participation in the agricultural research process: Implications for agricultural sustainability in Ethiopia. Int. J. Agric. Sustain. 2019, 17, 127-145. [CrossRef]

4. Drucza, K.; Rodriguez, M.d.C. Feminist Policy Analysis Implications for the Agricultural Sector in Ethiopia; International Maize and Wheat Improvement Center: Addis Ababa, Ethiopia, 2018.

5. Agarwal, B. Gender equality, food security and the sustainable development goals. Curr. Opin. Environ. Sustain. 2018, 34, 26-32. [CrossRef]

6. Food and Agriculture Organization of the United Nations. Women in Agriculture: Closing the Gender Gap for Development; State of Food and Agriculture 2010-11; Food and Agriculture Organization of the United Nations: Rome, Italy, 2011.

7. The World Bank; Food and Agriculture Organization of the United Nations; The International Fund for Agricultural Development. Gender in Agriculture Sourcebook; Agriculture and Rural Development, World Bank: Washington, DC, USA, 2009.

8. World Bank; ONE Campaign. Levelling the field: Improving opportunities for women farmers in Africa; World Bank: Washington, DC, USA, 2014.

9. United Nations. Sustainable Development Goals: Goal 2 Zero Hunger. Available online: https://www.un. org/sustainabledevelopment/hunger/ (accessed on 21 September 2020).

10. Food and Agriculture Organization of the United Nations. Sustainable Development Goals Indicator 5.a.2. Available online: https://www.un.org/sustainabledevelopment/gender-equality/ (accessed on 21 September 2020).

11. Omilola, B.; Robele, S. The Central Position of Agriculture within the 2030 Agenda for Sustainable Development; International Food Policy Research Institute: Washington, DC, USA, 2017.

12. Kabeer, N. 'Leaving No One Behind': The Challenge of Intersecting Inequalities; World Social Science Report 2016; UNESCO and the ISSC: Paris, France, 2016.

13. Gebre, G.G.; Isoda, H.; Rahut, D.B.; Amekawa, Y.; Nomura, H. Gender differences in the adoption of agricultural technology: The case of improved maize varieties in Southern Ethiopia. Womens. Stud. Int. Forum 2019, 76, 1-11. [CrossRef] [PubMed]

14. Quisumbing, A.R.; Kumar, N. Land Rights Knowledge and Conservation in Rural Ethiopia: Mind the Gender Gap; IFPRI Discussion Paper 01386; International Food Policy Research Institute: Washington, DC, USA, November 2014.

15. Badstue, L.; Elias, M.; Kommerell, V.; Petesch, P.; Prain, G.; Pyburn, R.; Umantseva, A. Making room for manoeuvre: Addressing gender norms to strengthen the enabling environment for agricultural innovation. Dev. Pract. 2020, 30, 541-547. [CrossRef] [PubMed] 
16. Kabeer, N. Resources, agency, achievements: Reflections on the measurement of women's empowerment. Dev. Chang. 1999, 30, 435-464. [CrossRef]

17. Tanellari, E.; Kostandini, G.; Bonabana, J. Gender impacts on adoption of new technologies: Evidence from Uganda. Afr. J. Agric. Resour. Econ. 2013, 9, 300-308. [CrossRef]

18. Doss, C.R. Twenty-Five Years of Research on Women Farmers in Africa: Lessons and Implications for Agricultural Research Institutions with an Annotated Bibliography; CIMMYT Economics Program Paper No. 99-02; International Maize and Wheat Improvement Center: Mexico City, Mexico, 1999.

19. Quisumbing, A.R.; Pandolfelli, L. Promising Approaches to Address the Needs of Poor Female Farmers; IFPRI Discussion Paper 00882; International Food Policy Research Institute: Washington, DC, USA, July 2009.

20. Udry, C. Gender, agricultural production, and the theory of the household. J. Polit. Econ. 1996, 104, 1010-1046. [CrossRef]

21. Ndiritu, S.W.; Kassie, M.; Shiferaw, B. Are there systematic gender differences in the adoption of sustainable agricultural intensification practices? Evidence from Kenya. Food Policy 2014, 49, 117-127. [CrossRef]

22. Sen, A. Gender and Cooperative Conflict; Wider Working Papers 18; UNU-WIDER: Helsinki, Finland, 1987.

23. Manda, J.; Mvumi, B.M. Gender relations in household grain storage management and marketing: The case of Binga District, Zimbabwe. Agric. Human Values 2010, 27, 85-103. [CrossRef]

24. Butler, J. Performative acts and gender constitution: An essay in phenomenology and feminist theory. Theatr. J. 1988, 40, 519-531. [CrossRef]

25. O’Brien, C.; Gunaratna, N.S.; Gebreselassie, K.; Gitonga, Z.M.; Tsegaye, M.; De Groote, H. Gender as a cross-cutting issue in food security: The NuME project and quality protein maize in Ethiopia. World Med. Health Policy 2016, 8, 263-286. [CrossRef]

26. Kassa, Y.; Kakrippai, R.S.; Legesse, B. Determinants of adoption of improved maize varieties for male headed and female headed households in West Harerghe Zone, Ethiopia. Int. J. Econ. Behav. Organ. 2013, 1, $33-38$. [CrossRef]

27. Tiruneh, A.; Tesfaye, T.; Mwangi, W.; Verkuijl, H. Gender Differentials in Agricultural Production and Decision-Making Among Smallholders in Ada, Lume, and Gimbichu Woredas of the Central Highlands of Ethiopia; International Maize and Wheat Improvement Center: Mexico City, Mexico, February 2001.

28. Ragasa, C.; Berhane, G.; Tadesse, F.; Taffesse, A.S. Gender differences in access to extension services and agricultural productivity. J. Agric. Educ. Exten. 2012, 19, 437-468. [CrossRef]

29. Nelson, K.M. Analysis of Farmer Preferences for Wheat Variety Traits in Ethiopia: A Gender-Responsive Study. Master's Thesis, Cornell University, Ithaca, NY, USA, 2013.

30. Ahmed, M.E. Poverty and Livelihood Strategies of Female-Headed Households in Rural Ethiopia: The Case of Libo Kemkem Woreda, South Gondar. Ph.D. Dissertation, Andhra University, Visakhapatnam, India, 2013.

31. Farnworth, C.R.; López, D.E.; Badstue, L.; Hailemariam, M.; Abeyo, B.G. Gender and agricultural innovation in Oromia Region, Ethiopia: From innovator to tempered radical. Gend. Technol. Dev. 2018, 22, 222-245. [CrossRef] [PubMed]

32. National Planning Commission. Growth and Transformation Plan II (Volume I); National Planning Commission of the Federal Democratic Republic of Ethiopia: Addis Ababa, Ethiopia, 2016.

33. Aregu, L.; Bishop-Sambrook, C.; Puskur, R.; Tesema, E. Opportunities for Promoting Gender Equality in Rural Ethiopia through the Commercialization of Agriculture; Working Paper No. 18; International Livestock Research Institute: Addis Ababa, Ethiopia, 2010.

34. Gella, A.; Tadele, G. Gender and farming in Ethiopia: An exploration of discourses and implications for policy and research. Ethiop. J. Soc. Sci. Humanit. 2015, 11, 1-28.

35. Fafchamps, M.; Quisumbing, A.R. Control and ownership of assets within rural Ethiopian households. J. Dev. Stud. 2002, 38, 47-82. [CrossRef]

36. Kumar, N.; Quisumbing, A.R. Policy reform toward gender equality in Ethiopia: Little by little the egg begins to walk. World Dev. 2015, 67, 406-423. [CrossRef]

37. Miller, D.; Tolina, E.T. Land to the tiller redux: Unlocking Ethiopia's land potential. Drake J. Agric. Law 2008, 13, 348-376.

38. Mulema, A.A.; Damtew, E. Gender-Based Constraints and Opportunities to Agricultural Intensification in Ethiopia: A Systematic Review; International Livestock Research Institute: Nairobi, Kenya, August 2016.

39. Holden, S.T.; Tilahun, M. Farm size and gender distribution of land: Evidence from Ethiopian land registry data. World Dev. 2020, 130, 1-16. [CrossRef] 
40. Muchomba, F.M. Women's land tenure security and household human capital: Evidence from Ethiopia's land certification. World Dev. 2017, 98, 310-324. [CrossRef] [PubMed]

41. Howard, P.; Smith, E. Leaving Two Thirds out of Development: Female Headed Households and Common Property Resources in the Highlands of Tigray, Ethiopia; Food and Agriculture Organization of the United Nations: Rome, Italy, September 2006.

42. Petesch, P.; Badstue, L.; Camfield, L.; Feldman, S.; Prain, G.; Kantor, P. Qualitative, comparative, and collaborative research at large scale: The GENNOVATE field methodology. J. Gend. Agric. Food Secur. 2018, 3, 28-53. [CrossRef]

43. Petesch, P.; Badstue, L.; Prain, G. Gender Norms, Agency, and Innovation in Agriculture and Natural Resource Management: The Gennovate Methodology; International Maize and Wheat Improvement Center: Mexico City, Mexico, 2018.

44. Alemayehu, M.; Meskele, M. Health care decision making autonomy of women from rural districts of Southern Ethiopia: A community based cross-sectional study. Int. J. Womens. Health 2017, 9, $213-221$. [CrossRef] [PubMed]

45. John, N.A.; Edmeades, J.; Murithi, L.; Barre, I. Child marriage and relationship quality in Ethiopia. Cult. Heal. Sex. 2019, 21, 853-866. [CrossRef] [PubMed]

46. Chuta, N. Young Women's Household Bargaining Power in Marriage and Parenthood in Ethiopia; Working Paper 166; Young Lives, Oxford Department of International Development: Oxford, UK, February 2017.

47. Kandiyoti, D. Bargaining with patriarchy. Gend. Soc. 1988, 2, 274-290. [CrossRef]

48. Shiferaw, N. Transformative Household Methodology, Ethiopia: Gender, Targeting and Social Inclusion; International Fund for Agricultural Development: Rome, Italy, October 2014.

49. Farnworth, C.; Sundell, M.F.; Nzioki, A.; Shivutse, V.; Davis, M. Transforming Gender Relations in Agriculture in Sub-Saharan Africa; Swedish International Agricultural Network Initiative (SIANI): Stockholm, Sweden, 2013.

50. Farnworth, C.R.; Stirling, C.M.; Chinyophiro, A.; Namakhoma, A.; Morahan, R. Exploring the potential of household methodologies to strengthen gender equality and improve smallholder livelihoods: Research in Malawi in maize-based systems. J. Arid Environ. 2018, 149, 53-61. [CrossRef]

51. Reemer, T.; Makanza, M. Gender Action Learning System: Practical Guide for Transforming Gender and Unequal Power Relations in Value Chains; Oxfam Novib: The Hague, The Netherlands, 2014.

52. United Nations Development Programme. Upscaling Community Conversations in Ethiopia: Unleashing Capacities of Communities for the HIV/AIDS Response; United Nations Development Programme: Addis Ababa, Ethiopia, 2004.

53. Farnworth, C.R.; Colverson, K.E. Building a gender-transformative extension and advisory facilitation system in Sub-Saharan Africa. J. Gend. Agric. Food Secur. 2015, 1, 20-39. [CrossRef]

Publisher's Note: MDPI stays neutral with regard to jurisdictional claims in published maps and institutional affiliations.

(C) 2020 by the authors. Licensee MDPI, Basel, Switzerland. This article is an open access article distributed under the terms and conditions of the Creative Commons Attribution (CC BY) license (http://creativecommons.org/licenses/by/4.0/). 